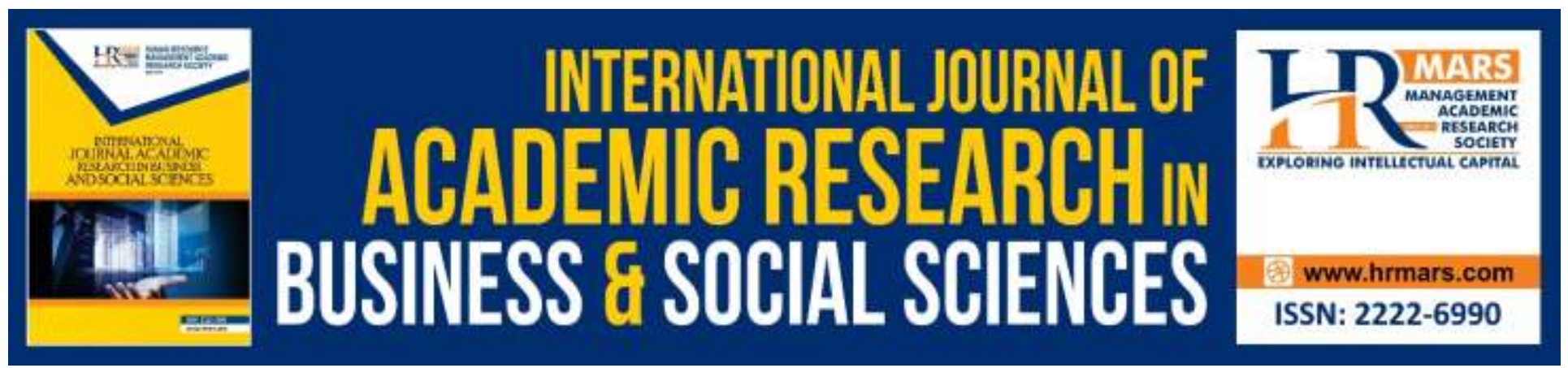

\title{
A Study on Effect of Capital Structure on the Financial Distress of Non-Financial Companies Listed in Bursa Malaysia Stock Exchange (KLSE)
}

\section{David Lee, Vikneswaran S/O Manual}

To Link this Article: http://dx.doi.org/10.6007/IJARBSS/v9-i6/5962

DOI: 10.6007/IJARBSS/v9-i6/5962

Received: 10 April 2019, Revised: 15 May 2019, Accepted: 05 June 2019

Published Online: 30 June 2019

In-Text Citation: (Leee, Manual, 2019)

To Cite this Article: Lee, D Manual, V. S. (2019). A Study on Effect of Capital Structure on the Financial Distress of Non-Financial Companies Listed in Bursa Malaysia Stock Exchange (KLSE). International Journal of Academic Research in Business and Social Sciences, 9(6), 428-450.

\section{Copyright: @ 2019 The Author(s)}

Published by Human Resource Management Academic Research Society (www.hrmars.com)

This article is published under the Creative Commons Attribution (CC BY 4.0) license. Anyone may reproduce, distribute, translate and create derivative works of this article (for both commercial and non-commercial purposes), subject to full attribution to the original publication and authors. The full terms of this license may be seen at: http://creativecommons.org/licences/by/4.0/legalcode

Vol. 9, No. 6, 2019, Pg. 428 - 450

Full Terms \& Conditions of access and use can be found at http://hrmars.com/index.php/pages/detail/publication-ethics 


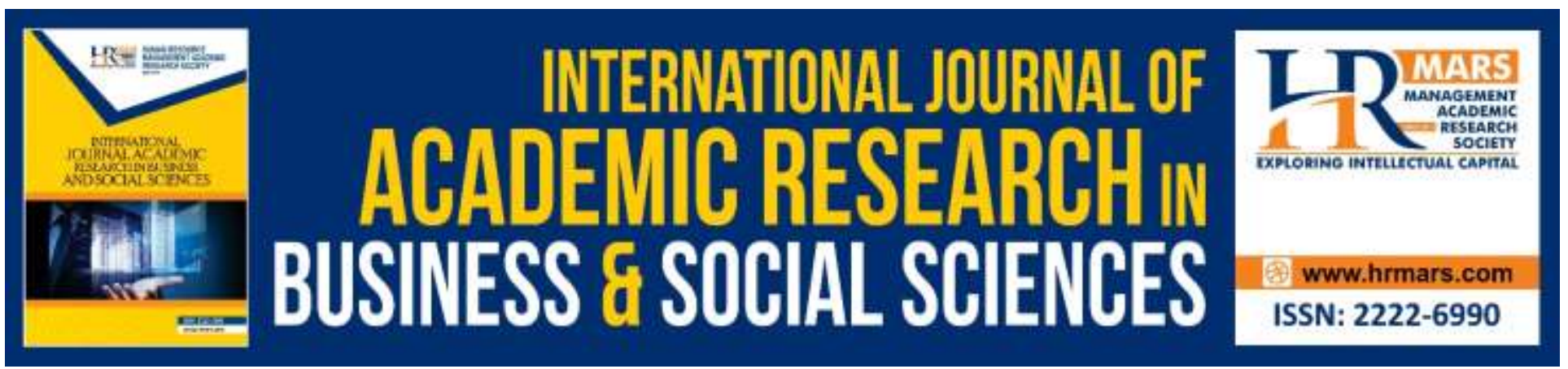

\title{
A Study on Effect of Capital Structure on the Financial Distress of Non-Financial Companies Listed in Bursa Malaysia Stock Exchange (KLSE)
}

\author{
David Lee \\ Asia Pacific University of Technology and Innovation \\ Vikneswaran S/O Manual \\ University Technology Malaysia, Kuala Lumpur, International Business School \\ Asia Pacific University of Technology and Innovation
}

\begin{abstract}
Inappropriate capital structure is one of the reasons the company goes into financial distress. Recently the average number of companies went bankrupt in Malaysia were increasing over the years. This also has been followed by increasing in the number of unlisted companies in KLSE. Therefore, it could be concluded that the number of companies went through financial distress in Malaysia becoming higher. The overall objective of the study is to find the effect of capital structure on the financial distress of non-financial companies listed in KLSE. Several independent variables which were financial leverage, debt maturity, equity structure, and asset structure had been taken into account to represent capital structure, and Altman Z-score used as the measurement of financial distress. Quantitative along with secondary data has been employed in this study extracted from 74 non-financial companies' financial statements published in KLSE from 2013 - 2017. OLS linear regression has been employed to help in answering the hypotheses. The study discovered that financial leverage, external equity, and assets tangibility has a negative and significant relationship towards financial distress, besides internal equity has a positive and significant relationship towards financial distress. However, debt maturity has a positive but insignificant relationship towards financial distress.
\end{abstract}

Keywords: Capital Structure, Financial Distress, Financial Leverage, Debt Maturity, Equity Structure, Asset Structure and Sales Growth 
INTERNATIONAL JOURNAL OF ACADEMIC RESEARCH IN BUSINESS AND SOCIAL SCIENCES

Vol. 9, No. 6, June, 2019, E-ISSN: 2222-6990 @ 2019 HRMARS

\section{Introduction}

\section{Background of the Study}

In recent years, many of corporate failures cases have been taken place, such as American International Group Inc., Philipp Holzmann, Enron, WorldCom, Swissair, Parmalat, and Bank of Credit and Commerce International (BCCl), which these give a reminder that giants and famous companies also could get into financial distress and bankruptcy. This leads to the concern of the corporations' financial health especially for the investors, and attracts many researchers to find the possible prediction for financial distress or bankruptcy of the corporate entities (Samanhyia, Oware, \& Yaansah, 2016). Financial distress can be avoided by firms through optimal strategies and financial decisions which in turn will help them in achieving their goals and encouraging their growth as well as the economy of the country (Turaboglu, et al., 2017). Besides, many of researchers) (Bei \& Wijewardana, 2012; Kristanti, et al., 2016; Mwangi, et al., 2014; Turaboglu et al., 2017; Zeni \& Amir, 2010) also mentioned that the main cause of financial distress is inappropriate of financial decisions, which mostly refer to the capital structure of the firm itself. Financial distress referred to the situation where the obligations could not be met by the organisation when it matured (Tin \& Nga, 2017). Capital structure defined as how the company is funding its businesses through the combination of debt and equity (Chadha \& Sharma, 2015). Mwangi, et al. (2014) stated that whether there is an optimal capital structure in the firm, it is one of the important things where the investors and management pay attention at. In addition, Rajkumar (2014) explained that in order to meet the optimal capital structure, the firms' management has to make sure that increases in the debt or equity should not decrease the value of the company.

Moreover, review of literature shows that capital structure still the most debateable element that could affect the financial distress level of the company. Studies carried out by Akhtar, et al. (2012), Gameel \& El-Geziry (2016), Kazemian, et al. (2017), Khaliq, et al. (2014), Kumar (2017), Velnampy (2013), Vithessonthi \& Tongurai (2013) have found that increasing in debt instrument could increase the financial distress level of the company. However, Abu-Rub (2012) and Bei \& Wijewardana (2012) found that increase in debt could decrease the financial distress level of the company. Moreover, Modigliani \& Miller (1958 (a)) and Pratheepkanth (2011) concluded that capital structure does not has any affect towards firm's financial distress kevel. Besides, the various results among the empirical studies could be explained by the different variables, measurement and target country that had been observed. Given this situation, it is necessary to undertake further observation on this area directly.

\section{Statement of the Problem}

According to Al-Khatib \& Al-Horani (2012), the researchers explained that global financial crisis happened in 2008 had resulted in many public listed companies in around the world were experiencing financial distress and ended with bankruptcy which in turn most economies around the world suffered financial disasters and setback. As a result, economists, financial analysts, and researchers debated the continuity of some companies and their ability to survive the financial distress and, thus, leading to the emergence of great interest to find the best methods and financial indicators that can help in the prediction of financial distress companies. Thus, this motivate the authors to take further study on this field. Financial distress seems to be an alarming issue in Malaysia lately, whereby according to figure 1.0, it shows that from 1998 until 2015, the corporate bankruptcy 
INTERNATIONAL JOURNAL OF ACADEMIC RESEARCH IN BUSINESS AND SOCIAL SCIENCES

Vol. 9, No. 6, June, 2019, E-ISSN: 2222-6990 @ 2019 HRMARS

in Malaysia has an average of 1249.71 . Besides, the statistic also shows that there is an increasing bankruptcy rate trend in Malaysia over the years.

\section{Figure 1.0 Malaysian Bankruptcy Statistic}

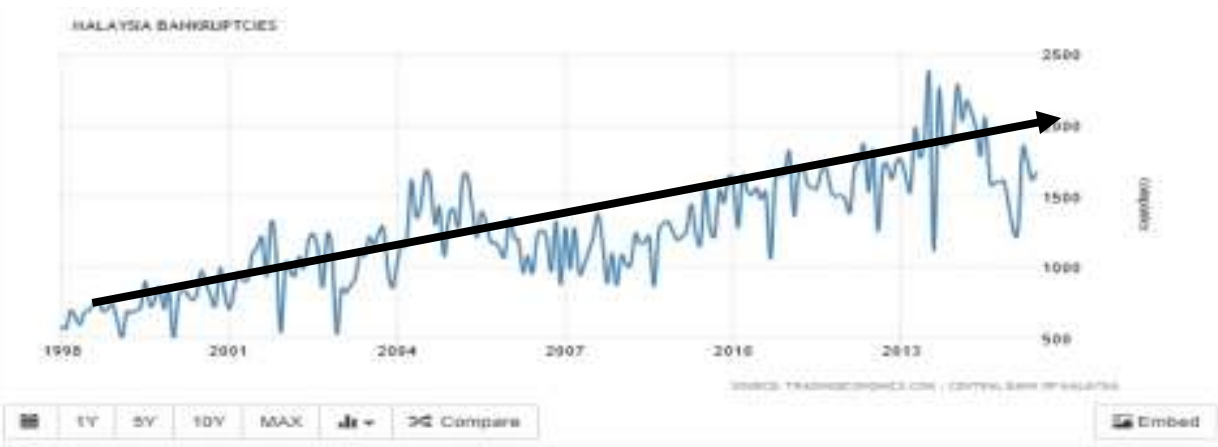

Source: (Trading Economics, 2018)

This trend of increasing in bankruptcy added by the financial crisis happened in 2008 also following by increasing the number of unlisted public companies in KLSE, which shown in the following figure 2.0.

Figure 2.0 Bursa Malaysia No. of Companies - Total

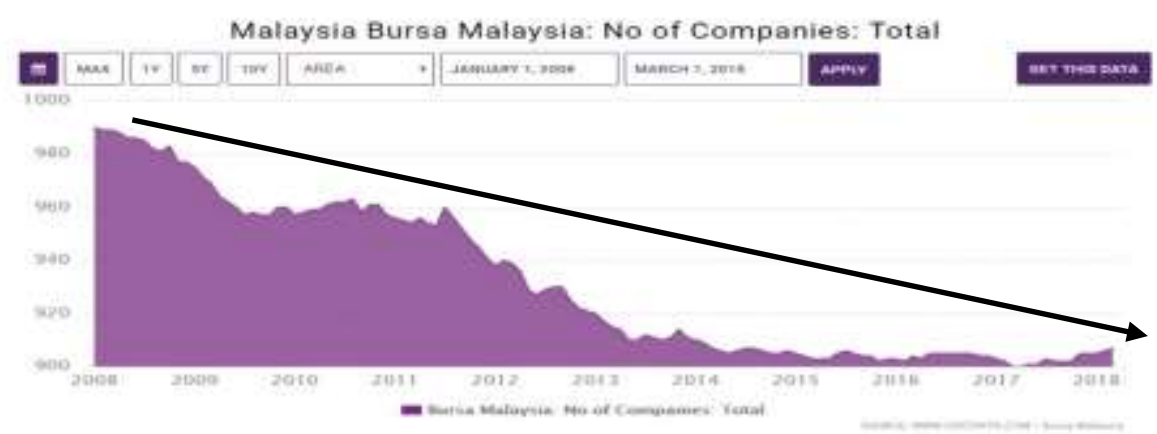

Source: (CEICdata, 2018)

However, less studies have been done in Malaysia. Many of them (Alifah, 2014 (b); Foo, et al. 2015; Khaliq, et al., 2014; and Noor, et al., 2012) have studied on factors as the indicators to measuring the financial distress but did not take many capital structure's variables into account. Such as financial leverage whereby Bei \& Wijewardana (2012) indicated that financial leverage helps company to improve its growth as financial leverage provides additional funds. Besides, Kristanti, et al. (2016) discovered that financial leverage would increase the risks of the company to experience distress. Additionally, Velnampy (2013) found that the longer the maturity of the debt, the more money could be invested by the company. In contrast, Hatem (2017) revealed that longer debt maturity, the riskier the company caused by the obligations and the possibility of fluctuations on the company's performance. Consequently, Asset structure which is tested by Leonard \& Mwasa (2014) also shows that high amount on tangible assets' account could bring high costs to the company if it does not utilise maximally. In another hand, Ezeoha (2008) explained that company with higher tangible assets will have a higher capability to borrow and reinvest in its business. Moreover, equity structure also 
play an important role, whereby Torre, et al. (2015) found that external equity will gives more pressure to the management and lead to increase in company's performance. Conversely, BarossoCastro, et al. (2015) stated that managers will feel more flexible in reinvesting the funds if there is more internal equity instead of external equity.

Added by the contradictions in empirical observations resulted in inconclusive outcomes and also increasing the bankruptcies in Malaysia which followed by the decreasing trends in public listed companies in KLSE, hence, it shows that there is a need to carry out further study in this area in Malaysia. The results of this study hope could help financial decision makers in the organisation to utilise the capital structure. Also investors and creditors in evaluating the financial distress level before investing their money in non-financial firms in KLSE. Regulatory policies such as government, capital market regulator and other policy in formulating appropriate mechanism which are necessary to continuously monitor and assess the financial condition of the listed companies.

\section{Research Objectives}

The study has the general intention to find the effect of capital structure on the financial distress of non-financial companies listed in KLSE. In fulfilling the general objective, the study will be guided by the following specific objectives:

- To identify the effect of financial leverage on the financial distress of non-financial companies listed in KLSE.

- To inspect the effect of debt maturity on the financial distress of non-financial companies listed in KLSE.

- To examine the effect of equity structure on financial distress of non-financial companies listed in KLSE.

- To determine the effect of assets structure on financial distress of non-financial companies listed in KLSE.

\section{Literature Review}

\section{Theoretical Review}

Several empirical theories were described in order to provide insight on the relationship between capital structure and financial distress.

\section{Theory or Capital Structure Irrelevance Hypothesis}

The hypothesis which has been established by Modigliani and Miller in 1958 has started the modern theory of capital structure. The authors developed that capital structure does not affect firm performance. Several assumptions have been considered into their hypotheses whereby market is fully efficient, there is no taxes and transaction costs, firms are operating in the same risk environment, borrowing costs for each companies and investors are no different, the dividend payout is 100 percent and no effect of debt on tax advantages (Ahmeti \& Prenaj, 2015; Modigliani \& Miller, 1958 (a)).

However, many critics have come out on this theory. According to Abeywardhana (2017), the author stated that the important contribution on the criticism of this theory was from the study conducted by Hirshleifer (1966) and Stiglitz (1969). Hirshleifer (1966) proved that market is not running perfectly, 
therefore, there must be cost of capital in every company. This also supported by Mondher (2011) evidenced that not all company around the world will distribute its profit 100 percent for dividend payment. Moreover, Stiglitz (1969) showed that in the real life, firms do not operate in homogenous business environment. The author also argued that firms and individual investors do not have a same level in market rates when borrowing. This also supported by the finding from Nenu, et al. (2018), whereby cost of debt of the firm is depending on its creditability and image.

\section{Trade-off Theory}

Modigliani and Miller (1963 (b)) have realized that taxes are exists in the real world, the authors have re-structured their irrelevant hypothesis and came out with the conclusion that capital structure is actually affect the value of the firm. The authors explained that the interest expenses consisted in debt financing can be used for lowering company's tax expenses, hence, it might help the company to generate extra cash inflow (Ghazouani, 2013; Liu, 2017).

\section{Agency Cost Theory}

Jensen \& Meckling (1976) has established agency theory. The theory explains that managers as the agent will not always work on the behalf of the principal, shareholders resulted in agency costs. Thus, the theory suggests that through increasing the leverage of the firm, it can help the firm to reduce its agency costs as the managers need to perform effectively to generate more profits from the amount borrowed in order to meet the obligations in the future, and creditors will monitor the managers performance as well, to make sure the firm does not default on its obligations (Grigore \& StefanDuice, 2013; lqbal, et al., 2012).

\section{Pecking Order Theory}

Pekcing-order theory has been established by Myers \& Majluf (1984) whereby the theory explains on the hierarchy of capital sources which the company will go first and to the last option. There are three sources of capital which are internal source referring to retained earnings, and also external sources referring to issuance of debt and equity (Abeywardhana, 2017). The theory states that due to there is information asymmetry and transaction costs (Culata \& Gunarsih, 2012; Dada, 2015; Myers \& Majluf, 1984; Singh \& Kumar, 2012), therefore the internal source should be the first choice for the company when it wants to raise its capital because it is more favourable due to free from cost incurred from information asymmetry, and followed by debt and the last one is external equity (Myers \& Majluf, 1984; Sharar, et al., 2015; Sigh \& Kumar, 2012; Tsuji, 2011). 
INTERNATIONAL JOURNAL OF ACADEMIC RESEARCH IN BUSINESS AND SOCIAL SCIENCES Vol. 9, No. 6, June, 2019, E-ISSN: 2222-6990 @ 2019 HRMARS

\section{Conceptual Framework}

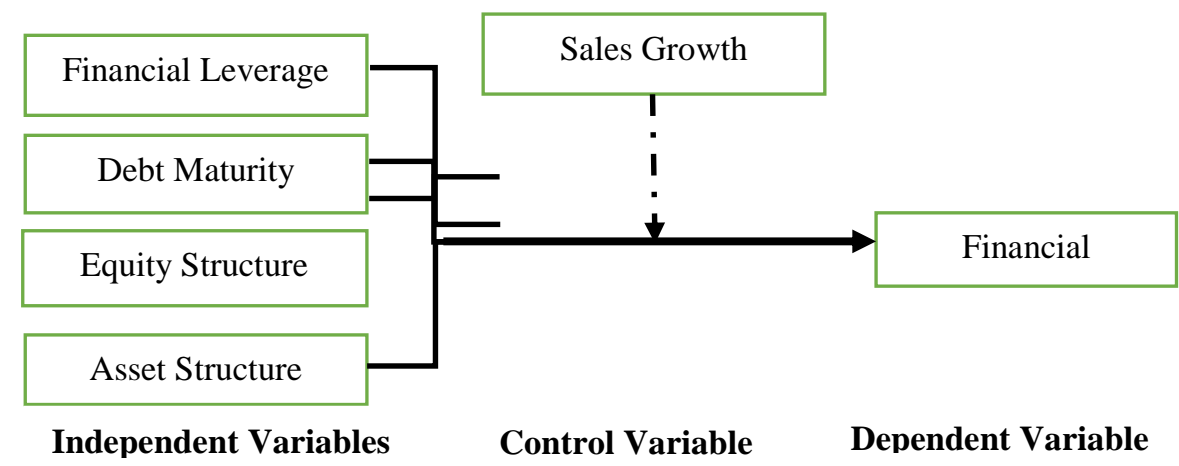

\section{Empirical Literature}

\section{Financial Leverage and Financial Distress}

Kumar (2017) defined financial leverage as on how extend the company uses fixed-income source of capital (debt and preferred stock) in relation to the equity within the capital structure. Several empirical studies conducted by Gameel \& El-Geziry (2016), Kazemian, et al. (2017), Kumar (2017), Khaliq, et al. (2014), Rouf, (2015), and Vitheesonthi \& Tongurai (2013) have discovered that financial leverage has a negative and significant relationship towards financial distress. In another hand, this finding is not in line with few empirical researchers who found there is a positive and significant relationship between financial leverage and financial distress such as the study conducted by ), and Abu-Rub (2012), and Bei \& Wijewardana (2012). However, Pratheepkanth (2011), and Wabwile, et al. (2014) revealed that there is no significant relationship between financial leverage and financial distress. Therefore, due to majority of previous researchers have found there is a significant relationship between the financial leverage and financial distress, this study will assume as follows: $H_{1} 1$ : Financial leverage has a significant effect on financial distress of nonfinancial firms listed in $K L S E$, in Malaysia

\section{Debt Maturity and Financial Distress}

Hatem (2017) defined debt maturity as how long the company has to pay back the amount of money that they borrowed to the lenders which divided into short and long-term debt. Previous empirical studies which have been completed by Lau, et al. (2016), Lee \& Dalbor (2013), Ogbulu \& Emeni (2012), Ogundipe, et al. (2012), and Vatavu (2015) have revealed that there is a positive and significant relationship between debt maturity and financial distress. Conversely, Abeywardhana \& Magoro (2017), Appiadjei (2014), Hatem (2017), and Yazdanfar \& Ohman (2015) have found contradict result whereby there is a negative and significant relationship between debt maturity and financial distress. Besides, Jayidding, et al. (2017) and Vatavu (2015) had discovered that there is no significant relationship between debt maturity and financial distress. Therefore, due to majority of previous researchers have found there is a significant relationship between debt maturity and financial distress, this study will assume as follows: 
INTERNATIONAL JOURNAL OF ACADEMIC RESEARCH IN BUSINESS AND SOCIAL SCIENCES

Vol. 9, No. 6, June, 2019, E-ISSN: 2222-6990 @ 2019 HRMARS

$H_{1}$ 2: Debt maturity has a significant effect on financial distress of non-financial firms listed in $K L S E$, in Malaysia.

\section{Equity Structure and Financial Distress}

Kihooto, et al. (2016) defined equity structure as the mixture of internally (retained earnings) and externally (issued shares) generated funds used in financing business operations. There were mix discovered results from empirical sturdies whereby some of them (Barosso-Castro, et al., 2015; Bassey, et al. 2016; Chidiebere, et al., 2014; Kihooto, et al., 2016; Thirumalaisamy, 2013) have uncovered internal equity has a positive and significant relationship towards financial distress, and external equity has an opposite relationship. On the other side, these empirical studies' result do not similar with the studies have been implemented by Ahmed \& Hadi (2017), Sciacscia \& Mazzola (2008), and Torre, et al. (2015) which found out that external equity has a positive and significant relationship towards financial distress. Nevertheless, Manzaneque, et al. (2016) noted that there is no significant relationship between equity structures towards financial distress for their study. Therefore, due to majority of previous researchers have found there is a significant relationship between the equity structure and financial distress, this study will assume as follows:

$H_{1}$ : Equity structure has a significant effect on financial distress of non-financial firms listed in $K L S E$, in Malaysia.

\section{Asset Structure and Financial Distress}

Leonard \& Mwasa (2014) defined asset structure as on how extent the company invest in their assets, either intangible or tangible assets. Several empirical studies which have been accomplished by Chadha \& Sharma (2015), Cuong \& Thang (2015), Leonard \& Mwasa (2014), and Muritala (2012) were revealed that here is a negative and significant relationship between tangibility towards firm performance. At the same time, the studies also oppose with empirical studies conducted by Ezeoha (2008), Harc (2015), Mwaniki \& Omagwa (2017), Olatunji \& Adegbite (2014), Setiadharma \& Machali (2017), and Xu \& Xu (2013) which discovered there is a positive and significant relationship between tangible assets and financial distress. However, Okwo, et al. (2012) found a dissimilar result whereby there is no a significant relationship between tangible assets and financial distress. Therefore, due to the majority of previous researchers have found there is a significant relationship between assets structures towards financial distress, this study will assume as follows:

$H_{1} 4$ : Asset structure has a significant effect on financial distress of non-financial firms listed in KLSE, in Malaysia.

\section{Financial Distress}

The first researcher who intended to study the predictors on financial distress was Beaver in 1966. Besides, due to univariate analysis model that had been used by the author, the model which has been established got so many critics. In response to those critics, Altman in 1968 has employed multivariate discriminant approach to financial distress prediction. Several models have been established accordance to the economy development of the country and industry, whereby the model known as Altman Z-score. In addition, this model was applied to test both Enron and WorldCom cases and the result were both companies in the danger zone in June 2001 before they 
INTERNATIONAL JOURNAL OF ACADEMIC RESEARCH IN BUSINESS AND SOCIAL SCIENCES

Vol. 9, No. 6, June, 2019, E-ISSN: 2222-6990 @ 2019 HRMARS

are going to bankrupt (Altman \& Hotchkiss, 2010). Begovic, et al. (2014) and Lubawa \& Louangrath (2016) added that this model has more than $85 \%$ accuracy on bankruptcy prediction, and it still the most popular technique in business failure identification.

\section{Methodology}

\section{Research Design}

Panel quantitative research design has been employed in this study, as the data was being analysed was the financial ratios of the company which is quantitative in nature and measureable through number. Cross-sectional and time series of the units being studies are required resulted the study chose panel data as the time horizon.

\section{Target Population and Sample Size}

The population of the study comprised the non-financial firms listed in KLSE which is 768 companies. There are several reasons on excluding financial firms into the population. Firstly is because there are tight regulatory controls regarding to the capital holding and liquidity requirements from the government. Furthermore, off-balance sheet policy is likely being applied by the financial institutions whereby it because not all the assets and liabilities are belong to the financial firms. Hence, it also can be concluded that the characteristics of financial and non-financial firms are different in nature. Thus, these conditions might distort the study's findings and conclusions (Altman, 2000; Muigai \& Mutiso, 2018). Therefore, because it just focusing on non-financial firms, judgemental sampling under non probability sampling method has employed and randomly 74 non-financial firms will be selected.

\section{Data Collection Procedures}

In order to help the study to reach its objectives, data from financial statements of individual nonfinancial firms during the five years period (2013-2017) is needed, hence, secondary data has been used in this study. Therefore, annual reports which have been published in KLSE Exchange became the source of the data collection of this study.

\section{Data Analysis}

Microsoft excel was used to compute the ratios for each variables of the observed company for every year (2013 - 2017). Descriptive statistics were employed to profile the pattern of observed companies. Moreover, several diagnostics tests were employed in order to test the validity of the observed data before employ the regression analysis. Lastly, panel regression analysis using Eviews version 10 was employed to test the relationship and significance between the independent variables and dependent variable. The significance level of the study was on 5 percent level. 
INTERNATIONAL JOURNAL OF ACADEMIC RESEARCH IN BUSINESS AND SOCIAL SCIENCES Vol. 9, No. 6, June, 2019, E-ISSN: 2222-6990 @ 2019 HRMARS

\section{Measurement of Study Variables}

The table below shows how the variables were measured in the study

Table 1.0 Measurement of the variables being studies

\begin{tabular}{|c|c|c|}
\hline Variables & Measurements & Adapted from \\
\hline \multirow{2}{*}{\multicolumn{3}{|c|}{$\begin{array}{l}\text { Independent } \\
\text { Variables }\end{array}$}} \\
\hline & & \\
\hline \multicolumn{2}{|l|}{ Financial Leverage } & Rouf (2015) \\
\hline Total equity (TE) & Total equity/ total assets & \\
\hline Total debt (TD) & Total liability/ total assets & \\
\hline \multicolumn{2}{|l|}{ Debt maturity } & Lau, et al. (2016) \\
\hline $\begin{array}{l}\text { Short-term debt } \\
\text { (STD) }\end{array}$ & $\begin{array}{l}\text { Total current liability/(total current liability }+ \\
\text { total current non-liability) }\end{array}$ & \\
\hline $\begin{array}{l}\text { Long-term debt } \\
\text { (LTD) }\end{array}$ & $\begin{array}{l}\text { Total Non-Current Liability / (Total Current } \\
\text { liability + Total Current Non-liability) }\end{array}$ & \\
\hline \multicolumn{2}{|l|}{ Equity Structure } & Torre, et al. (2015) \\
\hline Internal Equity (IE) & (Retained Earnings + Reserves) / Total Equity & \\
\hline External Equity (EE) & $\begin{array}{l}\text { (Paid-up share capital + share premium + } \\
\text { minority interest) / Total Equity }\end{array}$ & \\
\hline \multicolumn{2}{|l|}{ Asset Structure } & $\begin{array}{l}\text { Cuong \& Thang } \\
(2015)\end{array}$ \\
\hline Tangibility (TANG) & Total Fixed Assets / Total Assets & \\
\hline \multicolumn{3}{|l|}{ Control Variable } \\
\hline Sales Growth (SG) & $\left(\right.$ Sales $_{t}-$ Salest-1 $\left._{t}\right) /$ Salest-1 $_{t}$ & \\
\hline \multicolumn{2}{|l|}{$\begin{array}{l}\text { Dependent } \\
\text { Variables }\end{array}$} & $\begin{array}{l}\text { Begovic, et al. } \\
(2014)\end{array}$ \\
\hline
\end{tabular}

Financial Altman's Z-score Model for the emerging

Distress(FD) market

Z-score $=3.25+6.56 \mathrm{X}_{1}+3.26 \mathrm{X}_{2}+6.72 \mathrm{X}_{3}+1.05 \mathrm{X}_{4}$

Whereby: $Z$ - Score is the financial distress index for emerging market

$X_{1}$ is the ratio of working capital to total assets

$X_{2}$ is the ratio of retained earnings to total assets

$X_{3}$ is the ratio of earnings before interest and tax to total assets

$\mathrm{X}_{4}$ is the ratio of book value of owners' equity to book value of total liabilities

Zone Discrimination: Safe zone: Z-score > 5.85, Grey zone: $4.15<$ Z-score < 5.85, Distress Zone : Zscore $<4.1$

\section{Empirical Model Specification}

The regression model which has been estimated by the study to determine the relationship between the independent variables and dependent variable individually, shown as follows:

$$
F D_{i t}=\alpha_{0}+\alpha_{1} T_{i t}+\alpha_{2} S_{T D} \text { it }+\alpha_{3} L_{T D} \text { it }+\alpha_{4} \mathrm{IE}_{i t}+\alpha_{5} E_{i t}+\alpha_{6} T_{A N G} i t+\mu_{i t}
$$


INTERNATIONAL JOURNAL OF ACADEMIC RESEARCH IN BUSINESS AND SOCIAL SCIENCES Vol. 9, No. 6, June, 2019, E-ISSN: 2222-6990 @ 2019 HRMARS

Whereby:

$\mathrm{FD}_{\text {it }}=$ Financial distress, $\mathrm{TD}_{\mathrm{it}}=$ Total debt, $\mathrm{STD}_{\mathrm{it}}=$ Short-term debt, $\mathrm{LTD}_{\mathrm{it}}=$ Long-term debt, $\mathrm{IE}_{\mathrm{it}}=$ Internal equity, $\mathrm{EE}_{\mathrm{it}}=$ External equity, $\mathrm{TANG}_{\mathrm{it}}=$ Tangibility, $\alpha_{0}=$ Intercept term, $\alpha_{1-6}=$ the coefficients of independent variables, $\mathrm{i}=1 \ldots . .74, \mathrm{t}=$ time in years from $2013-2017$

\section{Results and Discussion}

Descriptive statistics

Table 2.0 Descriptive Summary Statistic on the Data Progressed

\begin{tabular}{|l|r|r|r|r|r|r|}
\hline Variables & \multicolumn{1}{|l|}{ Mean } & \multicolumn{1}{l|}{ Std. Dev. } & \multicolumn{1}{l|}{ Max } & \multicolumn{1}{l|}{ Min } & Skewedness & \multicolumn{1}{l|}{ Kurtosis } \\
\hline $\begin{array}{l}\text { Financial } \\
\text { Distress }\end{array}$ & 5.9947 & 2.4849 & 13.3130 & -2.772 & 0.4328 & 3.1326 \\
\hline External Equity & 0.6744 & 0.3564 & 2.5470 & -0.0150 & 1.0921 & 6.7724 \\
\hline Internal Equity & 0.3256 & 0.3565 & 1.0150 & -1.5470 & -1.0939 & 6.7669 \\
\hline Long term Debt & 0.2451 & 0.3071 & 1.0000 & 0.0000 & 1.0246 & 2.7409 \\
\hline $\begin{array}{l}\text { Short term } \\
\text { Debt }\end{array}$ & 0.7549 & 0.3071 & 1.0000 & 0.0000 & -1.025 & 2.7412 \\
\hline Total Debt & 0.1932 & 0.1863 & 0.9400 & 0.0000 & 1.2112 & 4.2560 \\
\hline Total Equity & 0.8068 & 0.1823 & 1.0000 & 0.1890 & -1.1454 & 3.9447 \\
\hline Tangibility & 0.6128 & 0.2684 & 0.9980 & 0.0000 & -0.3525 & 2.0186 \\
\hline Sales Growth & 0.7968 & 4.4374 & 57.7270 & -0.9800 & 8.7949 & 94.5198 \\
\hline
\end{tabular}

Table 2.0 shows that during the study period of the sample on non-financial firms listed in KLSE, the mean of the Z-score index of the progressed sample data is at 5.997 indicated that the majority of the observed companies were in the good health financially in relation to the Altman's distress zones. Furthermore, table 2.0 shows that majority of the observed companies were using external equity compared to internal equity whereby $67.44 \%$ and $32.56 \%$ respectively. It indicates that majority of the selected companies were utilising more share capital rather than retained earnings. Table 2.0 further shows that short-term debts were contributing more to the total debt compared to long-term debts among the observed non-financial firms' capital structure whereby the mean of those elements were $\mathbf{7 5 . 4 9 \%}$ and $24.51 \%$ respectively. It shows that among the observed non-financial companies were preferring short-term over long-term debt to finance their assets. this situation can be explained because long-term debt usually will be followed by high interest costs as the longer the time of borrowing periods, the riskier the possibility of the company to pay back the loan (Hatem, 2017). Furthermore, long-term debt also requires the company to provide high collateral for the security which not all companies are capable to meet it (Setiadharma \& Machali, 2017). Moreover, the results displayed in table 2.0 illustrated that among the selected non-financial firms, equity seems has contributed more to their capital structure compared to debt whereby the mean of each elements were $\mathbf{8 0 . 6 8 \%}$ and $19.32 \%$ respectively. Mendez (2013) also explained that company is more willing to finance its business using equity rather than debt due to debt will bring additional costs, and threat the credibility of the company, especially for small and medium companies. The results further showed in table 2.0 describe that among the observed non-financial firms, their total assets were 
approximately filled by non-current assets, whereby the mean of tangibility was $61.28 \%$ which was more than 50\%. However, the lowest value of this element was 0.0000 indicated that some companies were mostly do not have non-current assets in its total assets which can be indicator that the company is going to insolvency or experiencing financially distress. Brown, et al. (1994) explained that commonly distressed company do not have much non-current assets or even empty because this company will usually sell the fixed assets to pay back the loan.

\section{Diagnostic Tests}

\section{Panel Data Normality Test}

Normality test has been implemented in order to determine whether the data is normally distributed or not. There are two hypotheses which are as followed:

- $\mathrm{H}_{0}$ : The observed data is normally distributed

- $\mathrm{H}_{1}$ : The observed data is not normally distributed

According to figure 4.0 below, it shows that the probability is more than 0.05 (5\%) which is 0.3768 (37.68\%), hence, it indicates that it accepts null hypothesis and reject alternative hypothesis indicated that the observed data for each studied variables were normally distributed.

Figure 4.0 Panel Data Normality Test Results

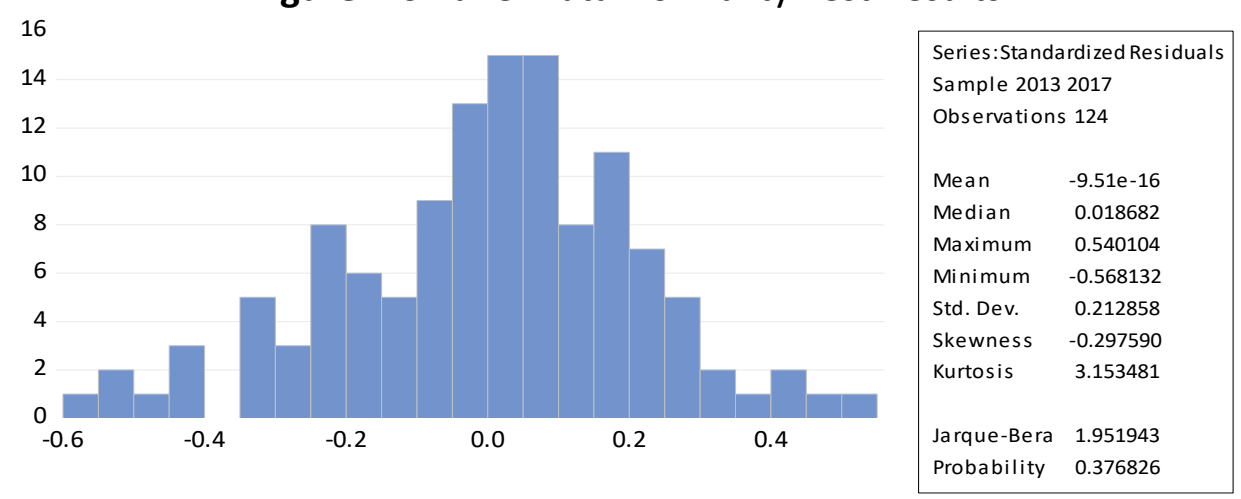

\section{Panel Unit Root Test}

This test to determine whether the panel data is stationary or not (Granger \& Newbold, 1974; Gujarati \& Porter, 2009). Under unit root tests, the hypotheses are:

- $\mathrm{H}_{0}$ : The observed data is non-stationary data

- $\mathrm{H}_{1}$ : The observed data is stationary data

Levin-Lin-Chu (LLC) (with trend) had been applied in this study because it has more appropriate concept compared to other panel unit root tests. The outputs of each panel root tests for each variables have been shown on table 3.0. 
INTERNATIONAL JOURNAL OF ACADEMIC RESEARCH IN BUSINESS AND SOCIAL SCIENCES

Vol. 9, No. 6, June, 2019, E-ISSN: 2222-6990 @ 2019 HRMARS

Table 3.0 Levin-Lin-Chu (LLC) (With trend) panel unit root test outputs

\begin{tabular}{lll}
\hline Variables & Statistics & P-value \\
\hline Financial Distress & -0.3547 & 0.0000 \\
\hline Total Equity & -0.3116 & 0.0000 \\
\hline Total Debt & -0.3150 & 0.0000 \\
\hline Short-Term Debt & -0.3421 & 0.0000 \\
\hline Long-Term Debt & -0.3421 & 0.0000 \\
\hline Internal Equity & -0.3381 & 0.0000 \\
\hline External Equity & -0.3361 & 0.0000 \\
\hline Tangibility & -0.2401 & 0.0000 \\
\hline Sales Growth & -1.0337 & 0.0000 \\
\hline
\end{tabular}

According to table 3.0 , it shows that all the variables have the $p$-value lower than $5 \%$. It indicates that the observed data was stationary since the $p$-value is lower than $5 \%$ meant that the null hypothesis was rejected, and alternative hypothesis was accepted.

\section{Heterescedasticity test}

Breusch-Pagan-Godfrey test has been employed to test whether the observed data got heterescedasticity problem or not (Gujarati \& Porter, 2009). There are two hypotheses under this test, which are:

- $\mathrm{H}_{0}$ : The observed data is homoscedasticity

- $\mathrm{H}_{1}$ : the observed data is heteroscedasticity

Table 4.0 Breusch-Pagan-Godfrey Test Results

\begin{tabular}{lrll}
\hline Breusch-Pagan-Godfrey test: Heteroscedasticity Test & \\
\hline F-Statistic & 1.449852 & Prob. F(9.114) & 0.1753 \\
\hline Obs*R-Squared & 12.73555 & Prob. Chi-Square(9) & 0.1749 \\
\hline Scaled Explained SS & 11.59031 & Prob. Chi-Square(9) & 0.2374 \\
\hline
\end{tabular}

According to table 4.0, it shows that the probability of F-statistic is more than the significant level of $5 \%$ which is 0.1753 , hence, the null hypothesis of the test is failed to be rejected meant that there is not heteroscedasticity problem among the observed data.

\section{Serial Correlation}

Serial correlation refers to a situation where the error terms of one distribution influence the other's observation data (Gujarati \& Porter, 2009), Dubin Watson test, and further test such as BreuschGodfrey serial correlation LM test had been employed to test the serial correlation between observed data with the hypotheses as follow:

- $\mathrm{H}_{0}$ : The independent variables are not auto correlate each other

- $\mathrm{H}_{1}$ : The independent variables are auto correlate each other 
INTERNATIONAL JOURNAL OF ACADEMIC RESEARCH IN BUSINESS AND SOCIAL SCIENCES Vol. 9, No. 6, June, 2019, E-ISSN: 2222-6990 @ 2019 HRMARS

Table 5.0 Dubin Watson and Breusch-Godfrey Autocorrelation Test

\begin{tabular}{|c|c|c|c|}
\hline \multicolumn{4}{|l|}{ Dubin Watson Test } \\
\hline Prob. (Fixed affect) & & & 1.8831 \\
\hline \multicolumn{4}{|c|}{ Breusch-Godfrey Serial Correlation LM Test } \\
\hline F-Statistic & 2.533951 & Prob. F (2.109) & 0.0839 \\
\hline Obs*R-Squared & 5.370580 & Prob. Chi-Square (2) & 0.0682 \\
\hline
\end{tabular}

According to table 5.0, it shows that the p-value for each test has exceeded $5 \%$ significant level (Dubin Watson $=1.8831$, and Breusch-Godfrey $=0.0682$ ). Therefore, null hypothesis for each tests are failed to be rejected, hence, it shows that the observed data is free from serial correlation.

\section{Multi co linearity}

\begin{tabular}{lcrlrrrrrr}
\hline & Z_score & EE & IE & LTD & STD & TD & TE & Tang & SG \\
\hline Z_score & 1.0000 & - & 0.3844 & - & 0.0634 & - & 0.3348 & - & -0.0341 \\
& & 0.3852 & & 0.0633 & & 0.3039 & & 0.6189 & \\
\hline EE & -0.3852 & 1.0000 & - & - & 0.1777 & 0.1185 & - & - & 0.0501 \\
& & & 0.9997 & 0.1778 & & - & 0.1284 & 0.0348 & \\
\hline IE & 0.3844 & - & 1.0000 & 0.1789 & - & - & 0.1293 & 0.0365 & -0.0501 \\
& & 0.9997 & & & 0.1788 & 0.1193 & & & \\
\hline LTD & -0.0633 & -0.1789 & 1.0000 & - & 0.2304 & - & 0.2261 & -0.0671 \\
& & 0.1778 & & & 1.0000 & & 0.2246 & & \\
\hline STD & 0.0634 & 0.1777 & - & - & 1.0000 & - & 0.2246 & - & 0.0671 \\
& & & 0.1788 & 1.0000 & & 0.2305 & & 0.2262 & \\
\hline TD & -0.3039 & 0.1185 & - & 0.2304 & - & 1.0000 & - & - & -0.0063 \\
& & & 0.1193 & & 0.2305 & & 0.9718 & 0.1796 & \\
\hline TE & 0.3348 & -0.1293 & - & 0.2246 & - & 1.0000 & 0.1759 & 0.0100 \\
& & 0.1284 & & 0.2246 & & 0.9718 & & & \\
\hline TANG & -0.6189 & -0.0365 & 0.2261 & - & - & 0.1759 & 1.0000 & -0.0810 \\
& & 0.0348 & & & 0.2262 & 0.1796 & & & \\
\hline SG & -0.0341 & 0.0501 & - & -0.0671 & - & 0.0100 & - & 1.0000 \\
& & & 0.0501 & 0.0671 & & 0.0063 & & 0.0810 & \\
\hline
\end{tabular}

Table 6.0 Correlation Coefficient Matric of the Regressions Variables

The results shown in table 6.0 shows that there are perfect negative correlations between long-term debts with short-term debts whereby the correlation result is (-1.000). In addition, there is almost perfect negative correlation between external equity with internal equity (With the correlation of (0.9997) and total debt with total equity (with the correlation of -0.9718). These results have been expected by the study as short-term debt and long-term debt is the two components of the total debt, external equity and internal equity is the two components of the total equity, and total debt 
and total equity is the two major components of capital structure, hence, one of this component if increasing or decreasing, its pair will be moved in the opposite direction. Besides, as what has been recommended by Gujarati \& Porter (2009) and Sekaran \& Bougie (2016) the other variables' correlation coefficients being well below 0.8 showed that the rest of variables do not have multicollinearity problem.

\section{Panel Model Regression Results and Hypothesis testing}

Hausman Test

There are two estimations effect under panel regression model which are random effect and fixed effect which both of it will produce different outputs, as the assumption of each effect is different from each other. Therefore, inappropriate affects would lead to higher error terms (Gujarati \& Porte, 2009). There are two hypotheses under this test, which are:

- $\mathrm{H}_{0}$ : Random effect model is the appropriate model

- $\mathrm{H}_{1}$ : Random effect model is no the appropriate model

Table 7.0 Hausman Test Results

\begin{tabular}{lrrr}
\hline Hausman Test & & & \\
\hline Test Summary & Chi-Sq. Statistic & Chi-Sq. d.f. & Prob. \\
\hline Cross-Section random & 29.120528 & & 9 \\
\hline
\end{tabular}

According to table 7.0, it shows that the p-value of Chi-square statistic is 0.0006 which is less than $5 \%$ significant level indicated that the study rejected null hypothesis and accepted alternative hypothesis. Therefore, fixed effect model is the appropriate model for estimating the panel equations. 
INTERNATIONAL JOURNAL OF ACADEMIC RESEARCH IN BUSINESS AND SOCIAL SCIENCES

Vol. 9, No. 6, June, 2019, E-ISSN: 2222-6990 (C) 2019 HRMARS

\section{Panel Regression Analysis}

\section{Table 8.0 Step-wise OLS (Fixed effects) Panel Regression Results}

Table 8.0 shows the results of step-wise OLS panel regression analysis estimated for fixed effects. The results further show that financial leverage has a negative and significant relationship towards financial distress. The conclusion based on the $p$-value corresponding to the coefficients of financial leverage variable equivalent to $0.0142,0.0000,0.0181$ and 0.0000 (for total debt in each equations) and $0.0001,0.0000,0.0004$, and 0.0000 (for total equity in each equations) which is less than $5 \%$, with the coefficients value for total debt is negative and total equity is positive. Therefore, this study accepted $\mathrm{H}_{1} 1$. This result is also supported by empirical studies carried out by several researches (Gameel \& El-Geziry 2016, Kazemian, et al. 2017, Kumar 2017, Khaliq, et al. 2014, Rouf, 2015, and Vitheesonthi \& Tongurai 2013). Kumar (2017) also stated that high finance costs resulted from the borrowing would increase the tendency level of the company on defaulting its obligations. Vithessonthi \& Tongurai (2013) added that this because due to high costs resulted from debt will lead to decrease in the profitability of the company, especially if the company uses the debt in an inefficient way. In addition, Rouf (2015) noted that default on meeting the debt obligations would

\begin{tabular}{|c|c|c|c|c|c|c|c|c|}
\hline \multicolumn{9}{|c|}{ Dependent Variable: Financial Distress } \\
\hline & Equation 1 & Equation 2 & Equation 3 & Equation 4 & Equation 5 & Equation 6 & Equation 7 & Equation 8 \\
\hline Variable & $\begin{array}{l}\text { Coefficient } \\
\text { (Prob.) }\end{array}$ & $\begin{array}{l}\text { Coefficient } \\
\text { (Prob.) }\end{array}$ & $\begin{array}{l}\text { Coefficient } \\
\text { (Prob.) }\end{array}$ & $\begin{array}{l}\text { Coefficient } \\
\text { (Prob.) }\end{array}$ & $\begin{array}{l}\text { Coefficient } \\
\text { (Prob.) }\end{array}$ & $\begin{array}{l}\text { Coefficient } \\
\text { (Prob.) }\end{array}$ & $\begin{array}{l}\text { Coefficient } \\
\text { (Prob.) }\end{array}$ & $\begin{array}{l}\text { Coefficient } \\
\text { (Prob.) }\end{array}$ \\
\hline Constant & $\begin{array}{r}(1.3814) \\
0.0000\end{array}$ & $\begin{array}{r}(1.0955) \\
0.0000\end{array}$ & $\begin{array}{r}(1.6955) \\
0.0000\end{array}$ & $\begin{array}{r}(1.6544) \\
0.0000\end{array}$ & $\begin{array}{r}(1.6343) \\
0.0000\end{array}$ & $\begin{array}{r}(1.9112) \\
0.0000\end{array}$ & $\begin{array}{r}(1.3677) \\
0.0000\end{array}$ & $\begin{array}{r}(1.9080) \\
0.0000\end{array}$ \\
\hline Total Equity & & & $\begin{array}{r}(0.5771) \\
0.0001\end{array}$ & $\begin{array}{r}(1.0102) \\
0.0000\end{array}$ & & $\begin{array}{r}(0.5275) \\
0.0004\end{array}$ & & $\begin{array}{r}(1.0227) \\
0.0000\end{array}$ \\
\hline Total Debt & \begin{tabular}{r|}
$(-0.0750)$ \\
0.0142
\end{tabular} & $\begin{array}{r}(-0.1294) \\
0.0000\end{array}$ & & & $\begin{array}{r}(-0.0719) \\
0.0181\end{array}$ & & $\begin{array}{r}(-0.1392) \\
0.0000\end{array}$ & \\
\hline $\begin{array}{ll}\begin{array}{l}\text { Short } \\
\text { debt }\end{array} & \text { Term } \\
\end{array}$ & & $\begin{array}{r}(-0.0572) \\
0.1617 \\
\end{array}$ & & $\begin{array}{r}(-0.0448) \\
0.2419 \\
\end{array}$ & & & $\begin{array}{r}(-0.0730) \\
0.0865 \\
\end{array}$ & $\begin{array}{r}(-0.0597) \\
0.1449 \\
\end{array}$ \\
\hline $\begin{array}{ll}\text { Long } & \text { Term } \\
\text { Debt } & \end{array}$ & $\begin{array}{r}(0.0002) \\
0.9891 \\
\end{array}$ & & $\begin{array}{r}(0.0110) \\
0.4980\end{array}$ & & $\begin{array}{r}(0.0109) \\
0.5953\end{array}$ & $\begin{array}{r}(0.0205) \\
0.2365\end{array}$ & & \\
\hline $\begin{array}{l}\text { External } \\
\text { Equity }\end{array}$ & $\begin{array}{r}(-0.2345) \\
0.0054\end{array}$ & $\begin{array}{r}(-0.3020) \\
0.0001\end{array}$ & $\begin{array}{r}(-0.2157) \\
0.0062\end{array}$ & $\begin{array}{r}(-0.2650) \\
0.0003\end{array}$ & & & & \\
\hline $\begin{array}{l}\text { Internal } \\
\text { Equity }\end{array}$ & & & & & $\begin{array}{r}(0.0365) \\
0.0181\end{array}$ & $\begin{array}{r}(0.0343) \\
0.1526\end{array}$ & $\begin{array}{r}(0.0772) \\
0.0013\end{array}$ & $\begin{array}{r}(0.0627) \\
0.0060\end{array}$ \\
\hline Tangibility & $\begin{array}{r}(-0.1802) \\
0.0058\end{array}$ & $\begin{array}{r}(-0.2388) \\
0.0003\end{array}$ & $\begin{array}{r}(-0.2217) \\
0.0004\end{array}$ & $\begin{array}{r}(-0.2728) \\
0.0000\end{array}$ & $\begin{array}{r}(-0.1606) \\
0.0146\end{array}$ & $\begin{array}{r}(-0.2058) \\
0.0014\end{array}$ & $\begin{array}{r}(-0.2233) \\
0.0006\end{array}$ & $\begin{array}{r}(-0.2731) \\
0.0000\end{array}$ \\
\hline Sales Growth & $\begin{array}{r}0.0419) \\
0.0001\end{array}$ & $\begin{array}{r}(0.0263) \\
0.0100\end{array}$ & $\begin{array}{r}(0.0341) \\
0.0008\end{array}$ & $\begin{array}{r}(0.0164) \\
0.0767\end{array}$ & $\begin{array}{r}(0.0274) \\
0.0236\end{array}$ & $\begin{array}{r}(0.0242) \\
0.0354\end{array}$ & $\begin{array}{r}(0.0144) \\
0.1927\end{array}$ & $\begin{array}{r}(0.0150) \\
0.3136\end{array}$ \\
\hline & Equation 1 & Equation 2 & Equation 3 & Equation 4 & Equation 5 & Equation 6 & Equation 7 & Equation 8 \\
\hline \multicolumn{9}{|l|}{ Statistics } \\
\hline R-Squared & 0.9474 & 0.9060 & 0.9537 & 0.9165 & 0.9492 & 0.9541 & 0.9074 & 0.9130 \\
\hline $\begin{array}{l}\text { Standard } \\
\text { Error }\end{array}$ & 0.1285 & 0.1624 & 0.1206 & 0.1526 & 0.1266 & 0.1203 & 0.1606 & 0.1551 \\
\hline $\begin{array}{ll}\text { Prob. } & (\mathrm{F}- \\
\text { Statistic) } & \\
\end{array}$ & 0.0000 & 0.0000 & 0.0000 & 0.0000 & 0.0000 & 0.0000 & 0.0000 & 0.0000 \\
\hline Observations & 370 & 370 & 370 & 370 & 370 & 370 & 370 & 370 \\
\hline
\end{tabular}

also reduce the creditability of the company led the company hard to raise the funds externally in the future. Furthermore, Kazemian, et al. (2017) mentioned that high debt also will make the creditors 
INTERNATIONAL JOURNAL OF ACADEMIC RESEARCH IN BUSINESS AND SOCIAL SCIENCES Vol. 9, No. 6, June, 2019, E-ISSN: 2222-6990 @ 2019 HRMARS

interfere in the business operations and it could lead agency costs increases. Besides, this finding is not in line with few empirical researchers who found there is a positive and significant relationship between financial leverage and financial distress such as the study conducted by Abu-Rub (2012) and Bei \& Wijewardana (2012) who argued that debt give additional funds for the company to be reinvested and generate more return, and debt will give tax-shield benefits. In addition, it also contradicts with studies carried out by Pratheepkanth (2011), and Wabwile, et al. (2014) who found there is no significant relationship between financial leverage and financial distress. The authors noted that different country has different characteristics, especially on the financial market. Underdeveloped country more likely will be followed by poor financial market development which might lead the business companies really depend on the debt.

Moreover, table 8.0 further shows that there is a positive and insignificant effect between debt maturity and financial distress of non-financial companies at $5 \%$ significance level. The conclusion is based on the fact that the $p$-values corresponding to the coefficients of long and short-term debt variables were more than $5 \%$ (0.05), and the coefficient values for LTD is positive and STD is negative. Thus, this study rejected its $\mathrm{H}_{1} 2$. The result of the study which is not significant also mirror with the study implemented by Vatavu (2015) and Jayidding, et al. (2017). The insignificant result of this study might be attributed from the missing values of some data from the observed companies, which this also supported by Vatavu (2015). Additionally, Jayidding, et al. (2017) argued the reason behind of not significant was that different industry has different capital structure characteristic, thus, some of them will be depending on long-term funds.

Furthermore, table 8.0 shows that there is a negative and significant relationship between external equity towards financial distress, and a positive and significant relationship among internal equity and financial distress. This evidenced from the corresponding of $p$-value for each variables are in significance level of $5 \%$ and the coefficients value for external equity is negative and positive for internal equity. Hence, this study accepted its $\mathrm{H}_{1} 3$. The result also similar with empirical findings discovered by Barosso-Castro, et al., (2015), Bassey, et al., (2016), Chidiebere, et al., (2014), Kihooto, et al., (2016), and Thirumalaisamy, (2013). Kihooto, et al. (2016) explained internal equity gives the company opportunity to maintain its cost of capital. Besides, Chidiebere, et al. (2014) added that when the retained earnings were fully utilised at the maximum level by the managers, this will bring positive effect, otherwise, it will bring negative effect as it shows the firm failed to generate more profit from the money which should be distributed to its shareholders. Likewise, Bassey, et al. (2016) added that raise the equity externally would increase the intervening of interested parties which lead to increase company' expenses resulting from increasing in the costs of capital, tighter disclosure requirements and dividend payment requirement. At the same time, the result of this study also contradict with few empirical studies carried out by Ahmed \& Hadi (2017), Sciacscia \& Mazzola (2008), and Torre, et al. (2015). The researchers argued that the more outside investors involving, the more pressure that the managers have to perform well.

Consequently, table 8.0 displays that that there is a negative and significant effect of asset structure on financial distress of non-financial firms at $5 \%$ significance level. Then, this study accepted its $\mathrm{H}_{1} 4$. The result is supported by the empirical studies accomplished by Chadha \& Sharma (2015), Cuong \& Thang (2015), Leonard \& Mwasa (2014), and Muritala (2012). Leonard \& Mwasa (2014) argued that when the firms have high fixed assets, the tendency to over-borrow would expose the firm to higher 
risks of financial distress. Moreover, Chadha \& Sharma (2015) and Muritala (2012) explained that when the tangible assets are not being utilised fully by the company in contributing to its business, the costs occurred by those assets will incur loss to the company rather than bringing profit. However, it is not in sequence with study completed by Okwo, et al. (2012) who found there is no significant relationship between the variables. The authors argued the reason behind is because some industries depend highly on tangible assets.

\section{Conclusion}

The study discovered that capital structure has significant effect towards financial distress. The results show that financial leverage, external equity and asset structure has a negative and significant relationship towards financial distress. Thus, increases in these variables will lead to decrease in company's Z-score value, hence, it increases the financial distress level of the company. Moreover, internal equity has a positive and significant relationship towards financial distress, thus, increases in internal equity will lead to decrease the financial distress level of the company. Besides, debt maturity has a positive but insignificant relationship towards financial distress. Therefore, the longer the maturity of the debt, it will decrease the financial distress level of the company, where it does. Based on the findings, it recommends that managers should reduce company's debt in order to decrease the risk of bankruptcy from the obligations, prefer long-term debt when additional funds from debt sources are needed as long maturity does not require the company to pay early, and lower the propositions of company's tangible assets by disposing the one that less contribute to firm's performance in order to decrease the costs. In addition, government and regulator should encourage the firm to prioritise in using internally generated capital compared to externally issued capital, such as introduce higher tax for dividend income, or impose higher stamp duties on externally issued capital. Last but not least, same as other empirical studies, this study still far from perfect, thus, future researchers should revise the results of this study in order to fill the gaps in the future. Further study should take additional variables into account, such as corporate governance and macroeconomic factors, focus on specific industry, qualitative study to get in deep and comparison between emerging and emerged country.

\section{Acknowlegement}

Special thanks to my supervisors, Mr. Vikneswaran S/O Manual who always be there to guide me scholarly throughout my research. This dissertation would have been impossible to be completed in a proper way without his supervision. Feeling very grateful to have a valuable opportunity to become his supervisee. Special thanks also go to Asia Pacific University for providing me a conducive learning environment and an access to useful scholarly publishers of academic journals and books which really helpful for me in completing my studies. 
INTERNATIONAL JOURNAL OF ACADEMIC RESEARCH IN BUSINESS AND SOCIAL SCIENCES

Vol. 9, No. 6, June, 2019, E-ISSN: 2222-6990 @ 2019 HRMARS

\section{References}

Abeywardhana, D. (2017). Capital Structure Theory: An Overview. Accounting and Finance Research, 6(1), 133-138.

Abeywardhana, D., \& Magoro, K. (2017). Debt Capital and Financial Performance: A Comparative Analysis of South African and Sri Lankan Listed Companies. Asian Journal of Finance \& Accounting , 9(2), 103-127.

Abu-Rub, N. (2012). Capital structure and firm performance: Evidence from Palestine. Journal of Money, Investment and Banking, 4(23), 109-117.

Ahmed, N., \& Hadi, O. A. (2017). Impact of Ownership Structure on Firm Performance in the MENA Region: An Emprical Study. Accounting and Finance Research, 6(3), 105-115.

Ahmeti, F., \& Prenaj, B. (2015). A Critical Review of Modigliani and Miller's Theorem of Capital Structure. International Journal of Economics, Commerce and Management, 3(6), 914-924.

Akhtar, S., Javed, B., Maryam, A., \& Saida, H. (2012). Relationship between Financial Leverage and Financial Performance: Evidence from Fuel \& Energy Sector of Pakistan. European Journal of Business and Management, 4(11), 7-17.

Altman, E. (2000). Predicting financial distress of companies: revisiting the Z-score. Stern School of Business, New York University, 9-12.

Altman, E. I. \& Hotchkiss, E., (2010). Corporate Financial Distress and Bankruptcy. 3rd ed. United States of America: John Wiley \& Sons, Inc.

Appiadjei, E. A. (2014). Capital Structure and Firm Performance: Evidence from Ghana Stock Exchange. Research Journal of Finance and Accounting, 5(16), 37-43.

Barroso-Castro, C., Villegas-Perinan, M., \& Casillas-Bueno, J. (2015). How boards' Internal and External Social Capital Interaxt to Affect Firm Perormance. Strategic Organization, 1-26.

Bassey, B. E., Edom, G. O., \& Aganyi, A. A. (2016). Assessing the Impact of Retained Profit on Corporate Performance: Emprical Evidence from Nigeri Mills Company, Calabr-Nigeria. European Journal of Business and Innovation Research, 4(1), 36-47.

Begovic, S. V., Momeilovic, M., \& Tomasevic, S. (2014). The Enterprise Creditworthiness Evaluation By Z" Score Model. Economic Themes, 52(2), 184-196.

Bei, Z., \& Wijewardana, W. (2012). Financial leverage, firm growth and financial strength in the listed companies in Sri Lanka. Social and Behavioral Sciences, 40, 709-715.

Brown, D. T., James, C. M., \& Mooradian, R. M. (1994). Asset sales by financially distressed firms . Journal of Corporate Finance, 1(1), 233-257.

CEICdata. ( 2018). Malaysia Bursa Malaysia: No of Companies: Total. Retrieved July 23, 2018, from https://www.ceicdata.com/en/malaysia/bursa-malaysia-number-of-listed-companies/bursamalaysia-no-of-companies-total

Chadha, S., \& Sharma, A. (2015). Capital Structure and Firm Performance: Emprical Evidence from India. SAGE Journal, 19(4), 295-302.

Chidiebere, M., Ekwe, \& Inyiama, O. I. (2014). Revenue Reserves and Financial Performance in the Brewery Industry: Evidence from NIgeria. Applied Economics and Finance, 1(2), 117-131.

Culata, P., \& Gunarsih, T. (2012). Pecking Order Theory and Trade-Off Theory of Capital Structure: Evidence from Indoneisan Stock Exchange. Journal The Winners, 13(1), 40-49. 
INTERNATIONAL JOURNAL OF ACADEMIC RESEARCH IN BUSINESS AND SOCIAL SCIENCES

Vol. 9, No. 6, June, 2019, E-ISSN: 2222-6990 @ 2019 HRMARS

Cuong, N., \& Thang, N. (2015). Firm Characteristics and Capital Structure Decision: Evidence from Seafood Processing Enterprises in the South Central Region of Vietnam. Research Journal of Finance and Accounting, 6(8), 69-84.

Dada, F. B. (2015). The Pecking Order Theory: Evidence from Listed Firms in Nigeria . International Finance and Banking, 2(2), 72-84.

Ezeoha, A. E. (2008). Firm size and corporate financial-leverage choice in a developing economy: Evidence from Nigeria. The Journal of Risk Finance, 9(4), 351-364.

Foo, V., Jamal, A. A., Karim, M. R., \& Ulum, Z. K. (2015). Capital Structure and Corporate Performance: Panel Evidence from Oil and Gas Companies in Malaysia. International Journal of Business Management and Economic Research, 6(6), 371-379.

Gameel, M., \& El-Geziry, K. (2016). Predicting Financial Distress: Multi Scenarios Modeling Using Neural Network. International Journal of Economics and Finance, 8(11), 159-166.

Ghazouani, T. (2013). The Capital Structure through the Trade-Off Theory: Evidence from Tunisian Firm. International Journal of Economics and Financial Issues , 3(3), 625-636.

Granger, C., \& Newbold, P. (1974). Spurious Regressions in Econometrics. Journal of Econometrics, 2(2), 111-120.

Grigore, M., \& Stefan-Duicu, V. (2013). Agency Theory and Optimal Capital Structure. Challenges of the Knowledge Society. Economics, 862-868.

Gujarati, D. M., \& Porter, D. C. (2009). Basic Econometrics (5th ed.). United States: McGraw-Hill.

Harc, M. (2015). The Relationship Between Tangible Assets and Capital Structure of Small and Medium-Sized Companies in Croatia. Economy Views, 28, 213-224.

Hatem, B. S. (2017). Influence of Debt Maturity on Firm Performance: An International Comparison. International Journal of Economics and Finance, 9(5), 106-113.

Hirshleifer, J. (1966). Investment Decision under Uncertainty: Applications of the State-Preference Approach. The Quarterly Journal of Economics, 80(2), 252-277.

Iqbal, S., Muneer, S., Jahanzeb, A., \& Rehman, S.-u. (2012). A Critical Review of Capital Structure Theories. Information Management and Business Review, 4(11), 553-557.

Jayiddin, N. F., Jamil, A., \& Roni, S. M. (2017). Capital Structure Influence on Construction Frim Performance. SHS Web of Conferences, 36, 1-9.

Jensen, M., \& Meckling, W. (1976). Theory of The Firm: Managerial Behavior, Agency Cost and Ownership Structure. Journal of Financial Economics, 3, 305-360.

Kazemian, S., Shauri, N. A., Sanusi, Z. M., Kamaluddin, A., \& Shuhidan, S. M. (2017). Monitoring mechanisms and financial distress of public listed companies in Malaysia. Journal of International Studies, 10(1), 92-109.

Khaliq, A., Altarturi, B., Thaker, H., Md Yousuf, H., \& Nahar, N. (2014). Identifying Financial Distress Firms: A Case Study of Malaysia's Government Linked Companies (GLC). International Journal of Economics, Finance and Management, 3(3), 141-150.

Kihooto, E., Omagwa, J., Wachira, M., \& Ronald, E. (2016). Financial Distress in Commercial and Services Companies Listed at Nairobi Securities Exchange, Kenya. European Journal of Business and Management, 8(27), 86-89.

Kristanti, F., Rahayu, S., \& Huda, A. (2016). The Determinant of Financial Distress on Indonesian Family Firm. Social and Behavioral Sciences, 219, 440-447. 
INTERNATIONAL JOURNAL OF ACADEMIC RESEARCH IN BUSINESS AND SOCIAL SCIENCES

Vol. 9, No. 6, June, 2019, E-ISSN: 2222-6990 @ 2019 HRMARS

Kumar, H. (2017). Financial Distress: Causes and Remedies. Inspira-Journal of Commerce, Economics \& Computer Science, 3(4), 409-412.

Lau, W. T., Law, S. H., \& Nassir, A. (2016). Debt Maturity and Stock Returns: an Inter-Sectoral Comparison of Malaysian Firms. Asian Academy of Management Journal of Accounting and Finance, 12(3), 37-63.

Lee, S., \& Dalbor, M. C. (2013). Short-Term Debt and Firm Performance in the US Restaurant Industry: The Moderating Role of Economic Conditions. Tourism Economics, 19(3), 565-581.

Leonard, M., \& Mwasa, I. (2014). Capital Structure and Financial Performance in Kenya: Evidence From Firms Listed at The Nairobi Securities Exchange. International Journal of Social Sciences and Entrepreneurship, 1(11), 209-223.

Liu, W. C. (2017). Trade-off theory of capital structure: evidence from estimations ofnon-parametric and semi-parametric panel fixed effect models. Investment Management and Financial Innovations, 14(1), 115-123.

Lubawa, G. \&. Louangrath, P., (2016). Using Altman Z-Score to Assess the Financial Effects of Multiple Loans on SMEs. International Journal of Research \& Methodology in Social Science, 2(1), pp. 63-88.

Manzaneque, Montserrat, Priego, A. M., \& Merino, E. (2016). Corporate governance effect on financial distress likelihood: Evidence from Spain. Revista de Contabilidad (Journal of Accounting), 19(1), 111-121.

Mendez, V. M. (2013). Determinants of debt maturity structure across firm size. Journal of Finance and Accounting, 42(158), 187-209.

Modigliani, F., \& Miler, M. (1958 (a)). The Cost of Capital, Corporation Finance and the Theory of Investment. The American Economic Review, 48(3), 261-297.

Modigliani, F., \& Miler, M. H. (1963 (b)). Corporate Income Taxes and the Cost of Capital: A Correction. The American Economic Review, 53(3), 433-443.

Mondher, K. (2011). A Re-examination of the MM Capital Structure Irrelevance Theorem: A Partial Payout Approach. International Journal of Business and Management, 6(10), 193-204.

Muigai, R. G. (2016). Effect of Capital Structure on Financial Distress of Non-Financial Companies Listed in Nairobi Securities Exchange . Kenya: Doctor of Philosophy, Jomo Kenyatta University of Agriculture and Technology.

Muritala, T. A. (2012). An Empirical Analysis of Capital Structure on Firms' Performance in Nigeria. International Journal of Advances in Management and Economics, 1(5), 116-124.

Mwangi, L., Makau, M., \& Kosimbei, G. (2014). Relationship between Capital Structure and Performance of Non-Financial Companies Listed In the Nairobi Securities Exchange, Kenya. Global Journal of Contemporary Research in Accounting, Auditing and Business Ethics, 1(2), 72-90.

Mwaniki, G., \& Omagwa, J. (2017). Asset Structure and Financial Performance: A Case of Firms Quoted Under Commercial and Services Sector at the Nairobi Securities Exchange, Kenya. Research Journal of Finance and Accounting, 8(4), 192-200.

Myers, S., \& Majluf, N. (1984). Corporate Finance and Investment Decisions When Firms Have Information That Investors Do Not Have. Journal of Financial Economics, 13, 187-221. 
INTERNATIONAL JOURNAL OF ACADEMIC RESEARCH IN BUSINESS AND SOCIAL SCIENCES Vol. 9, No. 6, June, 2019, E-ISSN: 2222-6990 @ 2019 HRMARS

Nenu, E., Vintila, G., \& Gherghina, S. (2018). The Impact of Capital Structure on Risk and Firm Performance: Empirical Evidence for the Bucharest Stock Exchange Listed Companies. International Journal of Financial Studies, 6(41), 1-29.

Noor, Z. M., Iskandar, T. M., \& Omar, N. (2012). Malaysian Companies Distress Prediction: DEA and Multinomial Logit Model . Prosiding Persidangan Kebangsaan Ekonomi Malaysia, 7, 15361551.

Ogbulu, O., \& Emeni, F. (2012). Capital Structure and Firm Value: Empirical Evidence from Nigeria. International Journal of Business and Social Science, 3(19), 252-260.

Ogundipe, S., Idowu, A., \& Ogundipe, L. (2012). Working Capital Management, Firms' Performance and Market Valuation in Nigeria. World Academy of Science, Engineering and Technology, 61(1), 1196-1200.

Okwo, I. M., Okelue, U. D., \& Nweze, A. U. (2012). Investment in Fixed Assets and Firm Profitability: Evidence from the Nigerian Brewery Industry. European Journal of Business and Management , 4(20), 10-17.

Olatunji, T., \& Adegbite, T. (2014). Investment in Fixed Assets and Firm Profitability: Empirical Evidence from the Nigerian Banking Sector. Asian Journal of Social Sciences and Management Studies, 1(3), 78-82.

Pratheepkanth, P. (2011). Capital structure and financial performance: Evidence from selected business companies in Colombo Stock Exchange, Sri Lanka. Journal of Arts, Science \& Commerce, 2(2), 171-183.

Rajkumar, P. (2014). Impact of Financial Leverage on Financial Performance: Special Reference to John Keells Holdings plc in Sri Lanka. Scientific Research Journal, 2(2), 15-20.

Rouf, M. A. (2015). Capital Structure and Firm Performance of Listed Non-Financial Companies in Bangladesh. The International Journal of Applied Economics and Finance, 9(1), 25-32.

Samanhyia, S., Oware, K. M., \& Yaansah, F. A. (2016). Financial Distress and Bankruptcy Prediction: Evidence from Ghana. Expert Journal of Finance, 4, 52-65.

Saunders, M., Lewis, P., \& Thornhill, A. (2016). Research Methods For Business Students (7th ed.). Harlow: Pearson Education Limited.

Sciascia, S., \& Mazzola, P. (2008). Family Involvement in Ownership and Management: Exploring Nonlinear Effects on Performance. Family Business Review, 21(4), 311-345.

Sekaran, U., \& Bougie, R. (2016). Research Methods for Business: A Skill-Building Approach (7th ed.). Chichester: John Wiley \& Sons.

Setiadharma, S., \& Machali, M. (2017). The Effect of Asset Structure and Firm Size on Firm Value with Capital Structure as Intervening Variable. Journal of Business \& Financial Affairs, 6(4), 1-5.

Singh, P., \& Kumar, B. (2012). Trade-off Theory vs Pecking Order Theory Revisited Evidence from India. Journal of Emerging Market Finance, 11(2), 145-159.

Stiglitz, J. E. (1969). A re-examination of the Modigliani-Miller theorem. The American Economic Review, 59(5), 784-793.

Thirumalaisamy, R. (2013). Firm Growth and Retained Earnings Behavior - A Study on Indian Firms. European Journal of Business and Management, 5(27), 40-57. 
INTERNATIONAL JOURNAL OF ACADEMIC RESEARCH IN BUSINESS AND SOCIAL SCIENCES

Vol. 9, No. 6, June, 2019, E-ISSN: 2222-6990 @ 2019 HRMARS

Tin, P. Q., \& Nga, T. T. (2017). Examining the Financial Distress Situation of Vietnamese Listed Firms Using Cash Flow Statements. South East Asia Journal of Contemporary Business, Economics and Law, 12(1), 16-31.

Torre, E., Pelagatti, M., \& Solari, L. (2015). Internal and External Equity in Compensation System, Organisational Absenteeism and The Role of Explained Inequalities. Human relations, 68(3), 409-440.

Trading Economics. (2018). Malaysia . Retrieved July 23, 2018, from https://tradingeconomics.com/malaysia/bankruptcies

Tsuji, C. (2011). An International Survey of the Evidence on the Pecking Order Theory of Corporate Financing. Business and Economic Rese arch, 1(1), 1-13.

Turaboglu, T., Erkol, A., \& Topaloglu, E. (2017). Financial Distress and Capital Structure Decision: An Aplication on BIST 100 Firms. Business and Economics Research Journal, 8(2), 247-258.

Vatavu, S. (2015). The impact of capital structure on financial performance in Romanian listed companies . Procedia Economics and Finance, 32, 1314-1322.

Velnampy, T. (2013). Corporate Governance and Firm Performance: A Study of Sri Lankan Manufacturing Companies. Journal of Economics and Sustainable Development, 4(3), 228235.

Vithessonthi, C., \& Tongurai, J. (2013). Financial Leverage and Operating Performance: Does Firm Size Matter? Journal of Multinational Financial Managament, 29, 1-29.

Wabwile, E. S., Chitiavi, M. S., Alala, O. B., \& Douglas, M. (2014). Financial Leverage and Performance Variance A Mong Banks. Evidence of Tier 1 Commercial Banks Listed On Nairobi Security Exchange Kenya. International Journal of Business and Management Invention, 3(4), 01-13.

Xu, Z., \& Xu, N. (2013). Research on the Optimal Allocation of Assets Structure and Corporation Management Performance: A Case Study of China Textile Machinery Co., Ltd. Asian Journal of Business Management, 5(4), 332-338.

Yazdanfar, D., \& Ohman, P. (2015). Debt financing and firm performance: an empirical study based on Swedish data. The Journal of Risk Finance, 16(1), 102-118.

Zeni, S. B., \& Ameer, R. (2010). Turnaround Prediction of Distressed Companies: Evidence From Malaysia. Journal of Financial Reporting and Accounting, 8(2), 143-159. 